\title{
A REVIEW ON SOLAR COOLING TECHNOLOGIES
}

\author{
Divik Mathur \\ Department of Mechanical Engineering, \\ Jaipur Engineering College and Research Centre, Jaipur, Rajasthan, India \\ mathurdivik@gmail.com
}

\begin{abstract}
Solar energy is a renewable and efficacious source of energy which is most fundamentally used in recent and evolving technologies. Solar Cooling is one such technology which uses the energy produced from the solar photo-voltaic cell to generate cooling which further can be utilized for refrigeration and air conditioning applications. Developments in the field of solar-powered cooling systems have increased the scope of future research and global usage. This paper provides a review and analysis of different solar cooling technologies that can be implemented to generate a cooling effect in various applications. In this paper, Solar Thermal and Electrical technologies are discussed with different attributes which can be utilised for comparison, reflecting the advantages and correct usage for each technology.
\end{abstract}

Keywords: Cooling technologies, photovoltaic cell, solar cooling, solar electrical cooling, solar thermal cooling.

Cite this Article: Divik Mathur, A Review on Solar Cooling Technologies. International Journal of Mechanical Engineering and Technology. 11(5), 2020, pp. 12-21.

https://iaeme.com/Home/issue/IJMET?Volume=11\&Issue $=5$

\section{INTRODUCTION}

As the growth rate of industrialization is increasing exponentially, energy consumption is also increasing rapidly. These energy requirements must be assisted well with renewable resources, as the dependency on fossil fuels will soon exhaust them fully. Studies show that the reserve for oil and natural gas will last up to 50 years [1]. Solar energy is the most fundamental and powerful source of renewable energy. It is easy to collect, available in abundance and environment-friendly. The potential estimates of Solar energy in India are about $68 \%$ [2]. Solar photovoltaic cells can efficiently generate energy from solar radiation. The photo-voltaic cells are semiconductor devices which transform solar energy into the electrical energy by the photoelectric effect. Use of several techniques in the scope of photovoltaic grids can generate maximum energy [3]. Experiments show that the efficiency of a photo-voltaic panel increases with a decrease in its temperature [4]. For every $274.15 \mathrm{~K}$ rise in temperature, the efficiency of the panel decreases by $0.4-0.65 \%$ [5]. The Research concluded 
that water cooling can enhance the efficiency of the panel by $14 \%$ [6]. Solar Cooling is a technique which takes energy from solar radiation and uses its energy to decrease the temperature and produces cooling. Solar Cooling technologies that are majorly used are Solar Thermal and Solar Electrical Cooling technology. In solar thermal cooling systems, the thermal energy generated from solar radiations is used to drive thermal cooling systems such as desiccant, absorption and adsorption cycles and in solar electrical cooling systems, electrical energy is used for conventional vapour compression cycles.

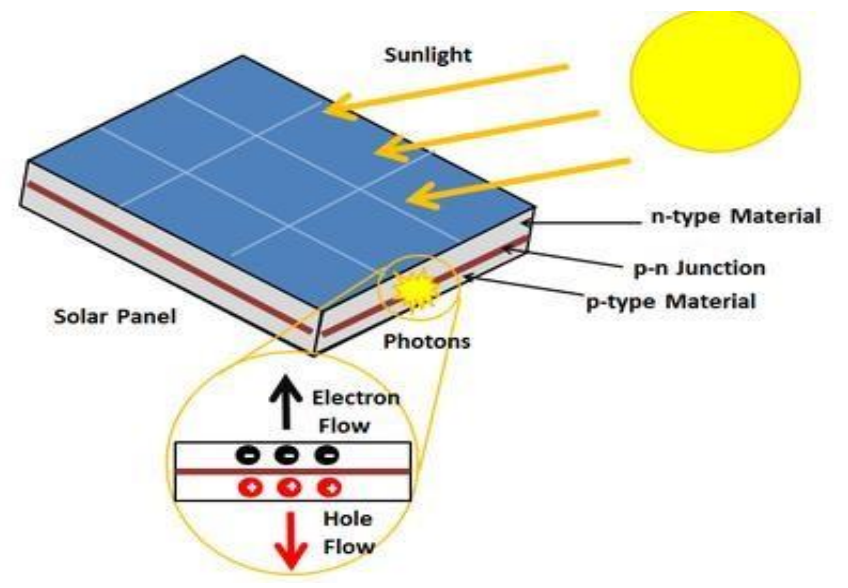

Figure 1 Diagram of a solar panel [20]

Thermoelectric technology based on Peltier effect can also be effectively used in solar cooling. Among other solar cooling technologies, absorption cooling has the highest COP of approximately 0.8 [7]. Further, these technologies are compared based on various attributes such as COP, cost, applications, size, etc.

Solar Cooling has great potential in future involvements in innovation and researches. It can fulfil the huge cooling demands with effective pollution control.

\section{LITERATURE REVIEW}

Yunho Hwang et al. [8] reviewed the solar-assisted cooling technologies based on their COP and efficiency. Further, the implementation of collector technology coupled with the technologies is discussed that will enhance the overall system efficiency. The performance of the solar technologies is evaluated and results are generated. They investigated, that the Adsorption cycle is more efficient because it required less heat source temperature. Also, vacuum tube collectors have higher solar collector efficiency. Future researches can help to achieve cheaper versions of flat plate collector with greater efficiency.

Albers et al. [9] reviewed developments on sorption cooling systems. Sorption process Solar Assisted Cooling can be achieved by either using closed-cycle to generate cold water and further using it fan coil units or ceilings and the heat is rejected by using a heat rejection coil, or by using an open cycle. Both technologies are further used with chillers. Optimum technology combination of system and collector can be founded by considering the cooling magnitude. Future innovations are for sure required to achieve an efficient chiller with optimized cost.

Abdul Ghafoor et al. [10] analysed different installed solar thermal cooling technologies based on several aspects such as COP, area of the collector (Ac), per unit chiller capacity and volume of the storage tank (V) per unit area of the collector. Further, the experimental data has been simulated. The simulated COP of a combination of solar thermal collectors and sorption chillers are greater than the experimental data. Also, the COP increases by increasing the hot water inlet temperature of the chiller. 
Abo Elmaaref et al. [11] investigated that the coefficient of thermo-electric performances can be enhanced by optimum design considerations and configuration. Use of better semiconductor metal can improve the efficiency of the system. Future development can improve thermoelectric based cooling technologies which can help in preventing O-zone depletion and will be a clean form of technology.

Ayman Jamal Alazazmeh et al. [12] reviewed and compared different solar cooling technologies i.e. solar electrical refrigeration system, thermo-mechanical combined power cooling systems and advanced triple effect refrigeration cycles based on different attributes. Then further, advantages and disadvantages can be made considering different attributes of comparison. Processes based on absorption cycles are implemented and used in the recent market by several different companies.

M. Usman [13] calculated the overall performance of the cooling technologies based on COP, capital cost, environmental Impact, operating temperature and technology maturity. Considering the advantages in each area, the best technology can be selected by blending the advantages of all. Also, Adsorption cooling is recommended for future improvement in this field.

Swapnil Ghatol et al. [14] discussed the use of the two-wheel desiccant system using solar heat for desiccant regeneration. A heat exchanger wheel is purposely matched with the desiccant wheel due to which, the heat exchanger recycles the heat for regeneration improving the efficiency. Research indicated that the Hybrid Desiccant/Vapour Compression Airconditioning can be a better option due to its 30 to $80 \%$ increase in energy saving. Simulations can be considered for energy saving when operating under variable load conditions. Systems like Dehumidifier with vapour compression system in series and indirect evaporative cooler can be considered for future research.

Salman Ajib et al. [15] analysed different available Solar Cooling Technologies based on different attributes to recognise their advantages and disadvantages. Technical input parameters considered are performance, humidity control, indoor air quality, energy storage capacity, installation and costs involved. Research indicated that the capacity of chiller is greatly affected by variations in the temperature range. Also, the temperature of the cold water depends on the magnitude of COP and refrigeration capacity.

Rishi et al. [16] analysed various factors that can be used in choosing the right solar cooling technology for suitable implementation. Factors considered are an effect of temperature on efficiency, solar radiation and operating conditions. Solar cooling techniques are also suggested such as active cooling, passive cooling, heat pipe cooling, nano-fluids and thermoelectric cooling. The study indicates that the efficiency of Passive cooling is generally low due to natural ventilation. Active cooling has higher efficiency so they can be implemented where large cooling is required. On the other hand, Active cooling is costly due to heavy maintenance in comparison to Passive cooling.

\section{CLASSIFICATION OF SOLAR COOLING TECHNOLOGIES}

Solar thermal cooling technology can be broadly classified into open and closed cycle technology. The comparison of open-cycle cooling technology includes solid and liquid desiccant systems. On the other hand, closed-cycle cooling technology includes the comparison of absorption and adsorption cooling technologies. Solar electrical cooling technologies can be categorised into thermo-electrical (Peltier) and vapour compression cycle technology. These are further compared based on key attributes. In Solar thermal cooling technologies, thermal energy generated from solar radiations is transformed to cooling through different chemical and physical processes. Open sorption cycle represents Desiccant 
systems that can be utilised for humidification and de-humidification in air-conditioning applications.

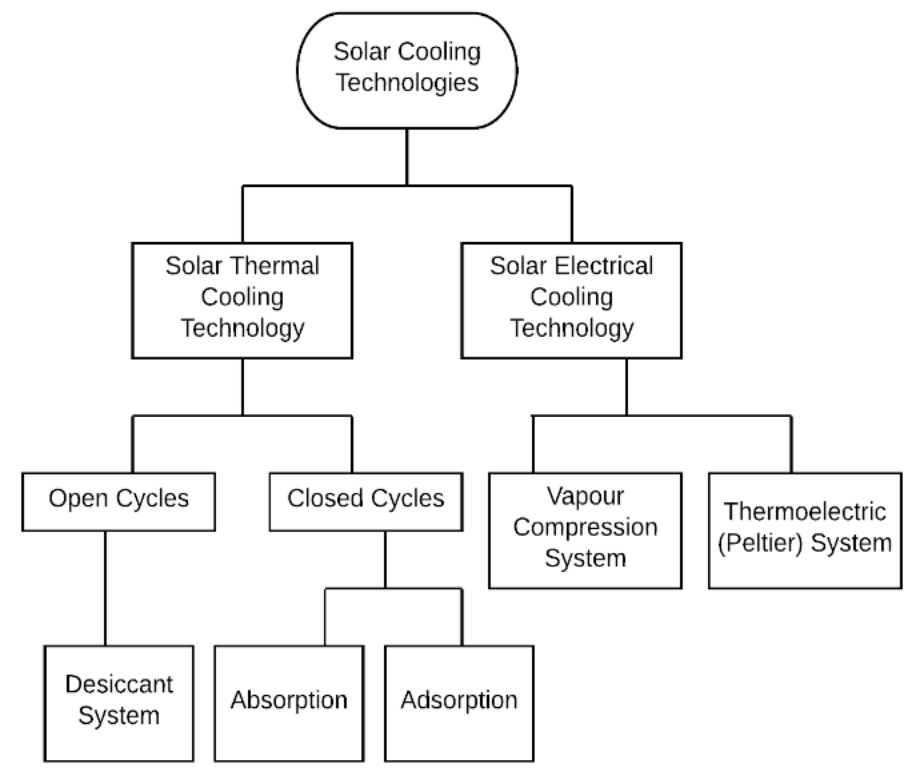

Figure 2 Classification of solar cooling technologies

These systems transfer moisture from one air stream to another. The liquid desiccant system uses a conditioner and a regenerator for generating the cooling. Dehumidification and regeneration are important processes for a liquid desiccant system. In solid desiccant systems, the air is passed through a solid desiccant such as silica gel for dehumidification and further to decrease its temperature by evaporative cooling. Closed sorption system represents absorption and adsorption cooling systems. Absorption cooling systems use a thermal compressor in its refrigeration cycle. The thermal compressor consists of an absorber and a generator. The basic absorption cycle can be depicted in fig. 3 .

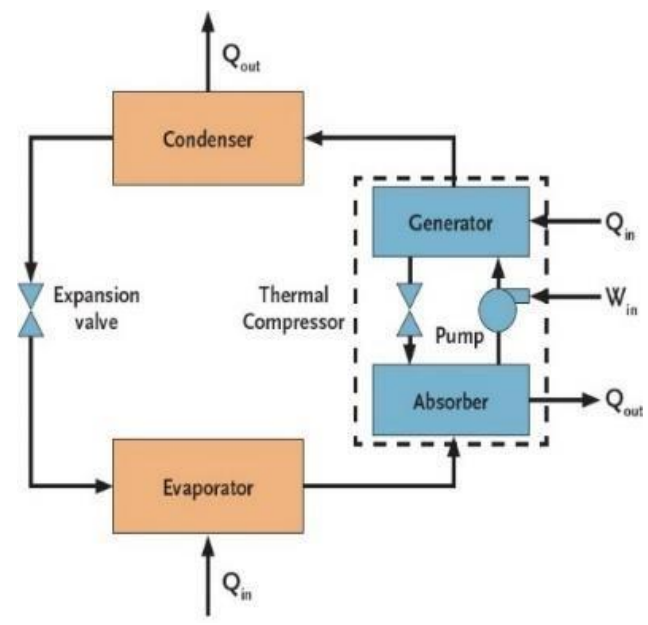

Figure 3 Schematic of absorption cycle [21]

In Adsorption cooling system, the refrigerant is absorbed on the surface of the solid sorbent material. The refrigerant thus forms a pair with the solid sorbent. Some commonly used pairs are water-silica gel and water zeolite. 
Solar electrical cooling systems use electricity obtained from photovoltaic panels for vapour compression systems and thermoelectric systems. Vapour compression systems use electricity generated by photovoltaic panel to drive mechanical compressors. These systems have a higher COP in comparison to other systems. The solar vapour compression cycle is represented in fig. 4.

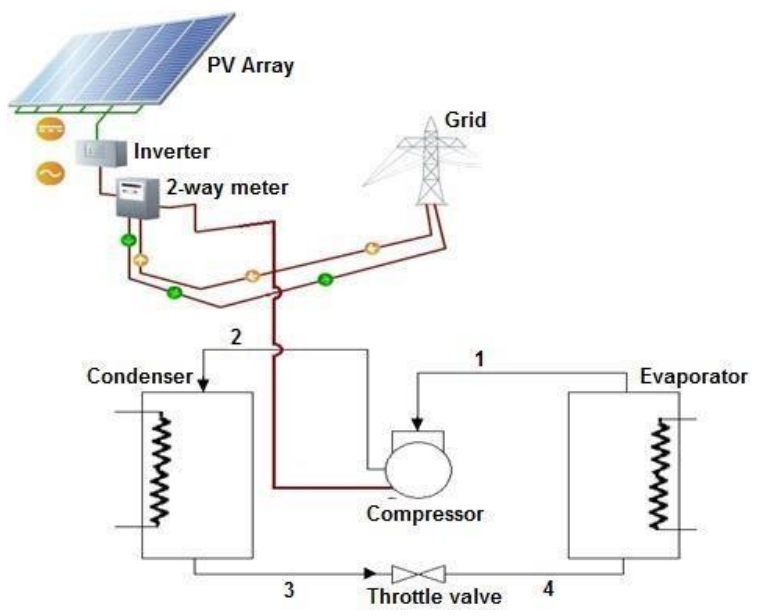

Figure 4 Solar vapour compression cycle [22]

Thermoelectric cooling technology uses the Peltier effect to generate cooling. A temperature difference is created when dissimilar electrodes connected with a semiconductor are given voltage. One side of the plate produces cooling and the other side produces heating. Thermoelectric cooling is less efficient than the compressor-based cooling systems.

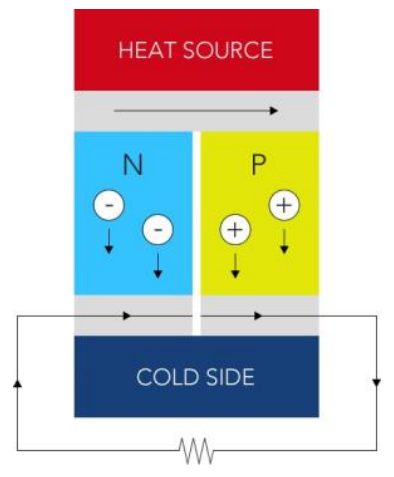

Figure 5 Thermoelectric cooling [23]

Fig. 5 represents thermoelectric effect. The efficiency of the whole module and system can be enhanced by using multi-stages [17].

\section{METHODOLOGY}

In this paper, a review of present solar cooling technologies is presented. The first step followed towards generating this review, is to create a database and further a literature review based on the rectified database. The literature review is an outline of different contributions by various authors on the relevant context. The next step towards the development of this review was to select the key attributes that will be used in the comparative study of the technologies. Further, the technologies are evaluated based on key attributes that are considered for analysing their potential. The key attributes considered in this review are Performance (COP), applications, cost, size (dimensions) and advantages \& disadvantages. 


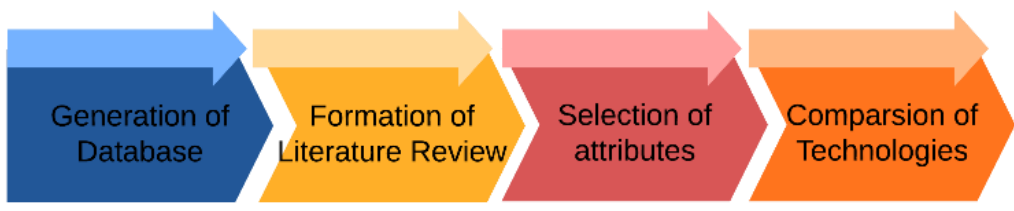

Figure 6 Methodology

\section{SELECTION OF KEY ATTRIBUTES}

The solar cooling technologies are compared based on some key attributes that can reflect their potential and ability to perform for a specific application as per the requirement. These attributes represent their performance parameters in terms of COP, their operating parameters and their advantages and disadvantages. Further, this comparison can help analyse and select the correct type of technology that can be implemented for a specific application. The key attributes that are considered for this review are shown in the table below-

Table 1 Key Attributes Considered for the Review

\begin{tabular}{|l|l|}
\hline \multicolumn{1}{|c|}{ Key Attribute } & \multicolumn{1}{c|}{ Criteria for Analysis } \\
\hline COP & Performance criteria \\
\hline $\begin{array}{l}\text { Size, Solar } \\
\text { Collectors }\end{array}$ & Design parameters \\
\hline $\begin{array}{l}\text { Cost, operating } \\
\text { range, working } \\
\text { fluid }\end{array}$ & Operational criteria \\
\hline Applications & Scope of implementation \\
\hline $\begin{array}{l}\text { Advantages, } \\
\text { Disadvantages }\end{array}$ & Pros \& Cons \\
\hline
\end{tabular}

\section{COMPARISON OF DIFFERENT SOLAR COOLING TECHNOLOGIES}

Different solar cooling technologies are implemented for different applications according to their potential and requirement. For selecting the technology to be implemented for a specific type of application, the technologies are compared by the help of the considered key attributes of the review. The analysis of this comparison can be utilised to select proper technology considering its performance, advantages \& disadvantages and operational cost.

1. In table 2, a comparison between Solar thermal closed-cycle technologies is made.

Table 2 Comparison between Solar Absorption and Adsorption Cooling Technology

\begin{tabular}{|l|l|l|}
\hline \multicolumn{1}{|c|}{ Key Attribute } & \multicolumn{1}{c|}{ Absorption Cooling } & \multicolumn{1}{c|}{ Adsorption Cooling } \\
\hline COP & $0.7-1.2$ & $0.6-0.8$ \\
\hline Size & Small & Large \\
\hline Cost & Low & High \\
\hline Operating range & $15 \mathrm{KW}-5 \mathrm{MW}$ & $50-430 \mathrm{KW}$ \\
\hline $\begin{array}{l}\text { Working } \\
\text { fluid }\end{array}$ & $\begin{array}{l}\text { Ammonia/ } \\
\text { Water or } \\
\text { LiBr/Water }\end{array}$ & $\begin{array}{l}\text { Refrigerant- Water } \\
\text { Adsorbent- Silica Gel }\end{array}$ \\
\hline Solar Collectors & Vacuum tube, concentrated & $\begin{array}{l}\text { Flat plate, vacuum Tube, } \\
\text { concentrated }\end{array}$ \\
\hline Applications & $\begin{array}{l}\text { Space cooling, chilled ceilings, } \\
\text { refrigeration, hospitals }\end{array}$ & $\begin{array}{l}\text { Underfloor cooling, fan coils, } \\
\text { refrigeration, laboratories }\end{array}$ \\
\hline
\end{tabular}




\begin{tabular}{|l|l|l|}
\hline Advantages & $\begin{array}{l}\text { Higher COP } \\
\text { higher reliability. } \\
\text { Smaller weight enhances the } \\
\text { efficiency of the cycle. }\end{array}$ & $\begin{array}{l}\text { Can be operated with a single flat } \\
\text { collector, lower operational } \\
\text { temperature range, simple design in } \\
\text { comparison to absorption system, } \\
\text { no risks of corrosion. }\end{array}$ \\
\hline Disadvantages & $\begin{array}{l}\text { Higher maintenance issues, } \\
\text { corrosion risks, higher maintenance } \\
\text { costs, only efficient and suitable for } \\
\text { larger buildings. }\end{array}$ & $\begin{array}{l}\text { Large sizes in comparison to the } \\
\text { absorption systems, longer run } \\
\text { cycle, lower COP. }\end{array}$ \\
\hline
\end{tabular}

Alazazmeh et al. [12] compare absorption and adsorption cooling technologies and the COP range can be referred from it. Prieto et al. [18] discuss the advantages and disadvantages of these technologies. Consideration of advantages can reflect the potential of the technology in fulfilling the required demand. Absorption cooling technology has higher maintenance issues due to more moving parts, and higher chances of corrosion.

2. In table 3, a comparison between Liquid and Solid Desiccant cooling system is made.

Table 3 Comparison between Solar Liquid and Solid Desiccant Cooling Technology

\begin{tabular}{|l|l|l|}
\hline \multicolumn{1}{|c|}{ Key Attribute } & \multicolumn{1}{|c|}{ Solid Desiccant cooling } & \multicolumn{1}{c|}{ Liquid Desiccant cooling } \\
\hline COP & $0.5-0.6$ & $0.6-0.8$ \\
\hline Size & Large & Small \\
\hline Cost & Low & High \\
\hline $\begin{array}{l}\text { Driving } \\
\text { temperature }\end{array}$ & $45-95^{\circ} \mathrm{C}$ & $45-70^{\circ} \mathrm{C}$ \\
\hline Working fluid & Water, silica gel & LiCl, LiBr, CaCl \\
\hline Solar Collectors & FPC/Solar air collectors & FPC/Solar air collectors \\
\hline Applications & Production of conditioned air. & $\begin{array}{l}\text { Used in existing fan coils, cold } \\
\text { storage }\end{array}$ \\
\hline Advantages & $\begin{array}{l}\text { Non-corrosive technology, low } \\
\text { maintenance costs, temperature } \\
\text { control, humidity flexibility. }\end{array}$ & $\begin{array}{l}\text { Higher dehumidification, scope of } \\
\text { high energy storage, higher COP, } \\
\text { continual passage of fresh air, } \\
\text { compact sized units. }\end{array}$ \\
\hline Disadvantages & Larger in size, complicated system. & $\begin{array}{l}\text { Corrosion risks, health hazards due } \\
\text { to supplied air streams, } \\
\text { crystallisation of salts, higher } \\
\text { maintenance costs. }\end{array}$ \\
\hline
\end{tabular}

Salman Ajib et al. [15] discusses the pros and cons of using liquid and solid desiccant systems. The Solid desiccant system is a non-corrosive technology with low maintenance. Considering performance parameter, liquid desiccant technology dominates over solid desiccant technology in terms of COP.

Gagliano et al. [19] investigate that the desiccant technology is about $40 \%$ more energy saver and it saves about $150 \%$ energy than the conventional vapour compression system.

3. In table 4, a comparison between Solar Thermo-electric (Peltier) cooling system and Solar Vapour compression cooling system is made. 
Table 4 Comparison Between Solar Thermo-Electric (Peltier) Cooling System and Solar Vapour Compression Cooling System

\begin{tabular}{|l|l|l|}
\hline \multicolumn{1}{|c|}{ Key Attribute } & Thermoelectric (Peltier) cooling & \multicolumn{1}{|c|}{ Vapour compression cooling } \\
\hline COP & $\sim 0.5$ & $1.5-4$ \\
\hline Size & Small & Large \\
\hline Cost & High & Low \\
\hline Working fluid & - & R134a, R407c, R410a \\
\hline Applications & $\begin{array}{l}\text { Solar refrigerators, automotive } \\
\text { cooling, semiconductor and } \\
\text { processor cooling }\end{array}$ & $\begin{array}{l}\text { Commercial and industrial } \\
\text { refrigerators, air-conditioning }\end{array}$ \\
\hline Advantages & $\begin{array}{l}\text { Small size. } \\
\text { No moving parts. } \\
\text { Does not produce sound. } \\
\text { Lightweight. } \\
\text { Absence of working fluid eliminates } \\
\text { the risk of leakage. }\end{array}$ & $\begin{array}{l}\text { Higher COP. } \\
\text { Easily available. } \\
\text { Quicker action. }\end{array}$ \\
\hline Disadvantage & $\begin{array}{l}\text { Lower COP. } \\
\text { High Cost. } \\
\text { Lower reliability. }\end{array}$ & $\begin{array}{l}\text { Requires more space. } \\
\text { Higher installation cost. } \\
\text { Complex design in comparison to } \\
\text { Peltier cooling. }\end{array}$ \\
\hline
\end{tabular}

Jatin Patel et al. [17] found that the COP of thermoelectric cooling can be increased by multistage TE module. Research indicates that the COP can be increased to 1.2151 by using a 3 stage TE module. Also, thermoelectric cooling does not contribute to the depletion of the Ozone layer due to absence of refrigerants. TE cooling can be a great scope of further research to enhance its COP up to the level of the conventional vapour compression system. Also, cost optimisation can be effective for further implementations.

4. A graphical comparison of the reviewed solar cooling technologies can also be made based on the performance criteria i.e. COP. Fig. 7 represents the graphical comparison between solar cooling technologies.

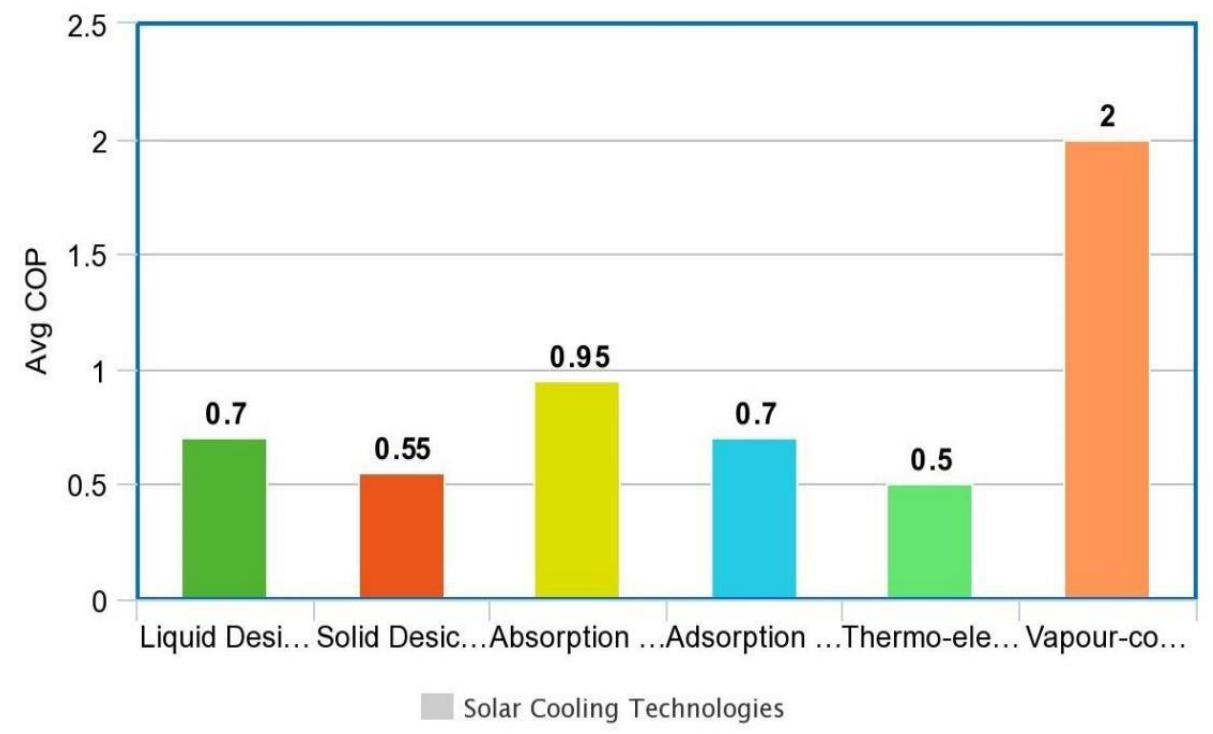

Figure 7 Graphical comparison based on average COP. 


\section{CONCLUSION}

Solar cooling has a great potential for research and development in future. The cooling demands are increasing due to environmental aspects and need for generation of artificially cooled surroundings for human comfort are also increasing. Several key aspects which are considered in the review can help in better understanding the potential and correct selection of technology for key implementation for specific applications. COP of adsorption and absorption cooling systems can be further enhanced by using optimum solar collectors and innovation in flat plate collector technology can enhance the overall efficiency of closed systems. Implementation of hybrid systems in case of open-cycle systems can be effective in improving the COP and ability to deal with variations in the operating temperature range. Also, the need to decrease energy consumption in vapour compression systems can be a great area of research. Future researches are to be made in the region of semiconductor components so that the thermoelectric technology can be enhanced further. Future works and researches can help improve and optimize technologies and make processes cost-effective.

\section{REFERENCES}

[1] V. Manieniyan, M. Thambidurai, and R. Selvakumar, "Study on Energy Crisis and the Future of Fossil Fuels," in Proc. SHEE, 2009 11-12 December.

[2] Energy Statistics 2009, Ministry of Statistics and Programme Implementation, Government of India.

[3] Trishnan Esram and Patrick L. Chapman, "Comparison of Photo-Voltaic Array Maximum Power Tracking Techniques,” IEEE, Vol. 22, pp. 439-449, June 2007.

[4] M.M. Rahman, M. Hasanuzzaman and N, A, Rahim, "Effects of Various Parameters on PV Module Power and Efficiency," Energy Conversion and Management, Vol. 103, pp. 348-258, October 2015.

[5] S. Nizetic, D. Coko, A. Yadav and F. Grubisic-Cabo, "Water Spray Cooling Technique Applied on a Photovoltaic Panel: The performance response," Energy Conversion and Management, Vol. 108, pp. 287-296, 2016.

[6] Khaled M Bataineh and Saja Alrifai, "Recent Trends in Solar Thermal Sorption System Cooling Technology," Advance in Mechanical Engineering, Volume 7(5) I-20, 2015.

[7] M. Pasamontes, J.D. Alvarez, J. L. Guzman and M. Berenguel, "Hybrid Modelling of a Solar Cooling System,” in IFAC Proc. Volumes, Vol. 42, pp. 26-31, 2009.

[8] Yunho Hwang, Reinhard Radermacher, Ali Al Alili and Isoroku Kubo, "Review of Solar Cooling Technologies," HVAC\&R Research, Vol 14, pp. 507-528, 2008.

[9] Jan Albers, Annett Kuhn, Stefan Petersan and Felix Zieglar, "Development and Progress in Solar Cooling Technologies with Sorption System," Chemie Ingenieur Technik, Vol. 83, pp. 1853-1863, 2011.

[10] Abdul Ghafoor and Anjum Munir, "Worldwide Overview of Solar Thermal Cooling Technologies," Renewable and Sustainable Energy Reviews, Vol. 43, pp. 763-774, March 2015.

[11] M. M. Abo Elmaaref, "Solar Thermoelectric Cooling Technology," Proc. of $3^{\text {rd }}$ International Conference on Energy Engineering Faculty of Energy Engineering - Aswan University-Aswan-Egypt, December 2015.

[12] Ayman Jamal Alazazmeh and Esmail M Mokheimer, "Review of Solar Cooling Technologies," Journal of Applied Mechanical Engineering, Vol. 4, Issue 5, September 2015. 
[13] Muhammad Usman, Qazi Shehzad Ali and Muhammed Bilal, "Assessment of Solar Cooling Technologies using the Analytical Hierarchical Process," World Journal of Engineering, Vol. 14, Issue 1, 2017.

[14] Swapnil Ghatol and Tejaswini Rajput, "Hybrid Solar Desiccant Cooling System," International Journal of Engineering Science and Research Technology, 6(12), pp. 569575, December 2017.

[15] Salman Ajib and Ali Alahmer, Solar Cooling Technologies, Energy Conversion - Current Technologies and Future Trends, Intech Open, November 2018.

[16] K Rishi, M Balachandran, G. Ragul, A. Srinivasagopalan, B. Ramkiran and P. Neelamagem, "Solar Cooling Technologies- A Review," in ICCPEIC, pp. 174-178, 2018

[17] Jatin Patel, Malik Patel, Jigar Patel and Himanshu Modi, "Improvement in the COP of Thermoelectric Cooler," International Journal of Scientific and Technology Research, Vol. 5, pp. 73-76, May 2016.

[18] Alejandro Prieto, Ulrich knaack, Thomas Auer and Tillmann Klein, "COOLFACADE: State of the Art Review and Evaluation of Solar Cooling Technologies on their Potential for Façade Integration”, Renewable and Sustainable Energy Reviews, Vol. 101, pp. 395 414, March 2019.

[19] Antonio Gagliano, Francesco Patania, Francesco Nocera and Aldo Galesi, "Performance assessment of a solar Assisted Desiccant Cooling System," Thermal Science 2014, Vol. 18, pp. 563-576, 2014.

[20] Created internally by a member of the Energy Education team. Adapted from: Ecogreen Electrical. (August 14, 2015). Solar PV Systems [Online] Available:

http://www.ecogreenelectrical.com/solar.htm

[21] Module 10: Absorption Refrigeration, CIBSE Journal [Online] Available: https://www.cibsejournal.com/cpd/modules/2009-11/

[22] Ammar Bany Ata and Handri Ammari, "Economic Comparison between PV Powered Vapor Compression Refrigeration System and Solar Thermal Powered Absorption Refrigeration System," 5th Jordanian IIR International Conference on Refrigeration and Air Conditioning, 2015.

[23] Thermoelectric effect [Online], Available: https://en.wikipedia.org/wiki/Thermoelectric_effect 